\title{
Türkiye'de orman yangını sorunu: Güncel bazı konular üzerine değerlendirmeler
}

\author{
Mustafa Avcia,* (D), Mehmet Korkmaz ${ }^{\mathrm{a}}$ (iD
}

\begin{abstract}
Özet: Bu çalışma ile Türkiye'de son yıllarda çıkan orman yangınlarının sayı ve alansal olarak değişiminin incelenmesi ve yangınların çıkış sebepleri itibariyle analiz edilmesi, orman yangınları konusunda zaman zaman tartışmaların da yaşandığı bazı konular hakkında değerlendirmeler yapılması ve bu bilgiler ışı̆̆ında orman yangınlarının önlenmesi ve mücadelesinde faydalı olacağı düşünülen öneriler getirilmesi hedeflenmiștir. Bu kapsamda Orman Genel Müdürlüğünün yangın kayıtları değerlendirilmiş ve orman yangınlarıyla mücadele tecrübesine sahip 22 uzman ile mülakatlar yapılmıştır. Sonuç olarak; yangın verilerinin değerlendirilmesiyle Türkiye'de yangın sayılarının genel olarak artma eğiliminde olduğu, alansal olarak bir azalma eğiliminin görüldüğü ancak bazı yıllar gerçekleşen birkaç büyük yangın nedeniyle kimi yıllar önemli artışlar olduğu görülmektedir. Yangınların çıkış sebepleri itibariyle dikkat çeken en önemli husus sebebi bilinmeyen yangınların son yıllarda arttığı ve tüm yangınların artık yarıdan fazlasının "meçhul" olarak kayıtlara geçtiği şeklindedir. Orman yangınları ile ilgili olarak Türkiye'de güncel sorunların; yangın sayılarının artması, iklim değişikliği ve kuraklığa bağlı olarak yangına hassas alanların genişlemesi ve yanıcı madde birikiminin ve sürekliliğinin artmasına bağlı olarak çıkan yangınların büyümesi, yangın sebeplerinin belirlenmesindeki eksiklikler, deneyimli yangın işçisi sayısının azlığı olduğu görülmüşsür.

Anahtar kelimeler: Orman yangınlarını önlenmesi, Orman yangınları ile mücadele, Toplumsal algılar, İklim değişikliği, Türkiye
\end{abstract}

\section{Forest fire problems in Turkey: Evaluations of some current issues}

\begin{abstract}
In this study, the number and spatial changes in forest fires in Turkey over recent years were examined and the causes of the fires analyzed. Evaluations were made concerning issues on which there were discussions about forest fires from time to time, and suggestions for reduction and prevention of forest fires were made. Fire records of the General Directorate of Forestry were evaluated, and interviews conducted with 22 experts with experience in fighting forest fires. Evaluation of the fire data showed that the number of forest fires in Turkey has increased in general, with decreasing trends noted in terms of area. There are significant increases in fire areas in some years due to a few big fires taking place. The most important point that draws attention in terms of the causes of the fires is that those of unknown cause have increased in recent years, with more than half of all fires are now recorded as "unknown". Current problems in Turkey regarding forest fires include increasing numbers of fires, fire sensitive areas due to heating and drought have increased, lack of understanding of the causes of fire, and the low number of experienced fire workers.
\end{abstract}

Keywords: Prevention of forest fires, Combating forest fires, Social perceptions, Climate change, Turkey

\section{Giris}

Ormanlar, barındırdığı tüm organizmalar ile birlikte oldukça dinamik bir yapıya sahip ekosistemler olarak zaman zaman büyük ölçüde insan kaynaklı tehlikelere maruz kalmakta ve devamlılıkları tehlikeye düşmektedir. Biyotik ve abiyotik faktörler olarak sınıflandırılan bu etkenler içinde insan kaynaklı yangınlar, ormanların sürekliliğini tehlikeye atan en önemli faktörlerden biridir. Yangınlar, ülkemizle birlikte diğer Akdeniz ülkeleri ve Avustralya ile ABD'nin bazı bölgelerinde de ormanların geleceğini tehdit etmektedir. Türkiye'nin önemli bir bölümünde, ülkenin yer aldığı coğrafya itibariyle yangınlar açısından uygun meteorolojik koşulların bulunması, daha kolay yanma özelliklerine sahip bitki örtüsü ile kaplı olması ve kıyı bölgelerinde yangın sezonu boyunca yoğun nüfus hareketleri nedeniyle her yıl çok sayıda orman yangını çıkmaktadır.

Orman Genel Müdürlüğü (OGM) 182 yıllık bilgi birikimi ve kurumsal yapısı ile ülkenin ormanlarını koruyan ve geliştiren önemli bir kamu kurumudur. OGM, iyi bir organizasyon kurmuş, sürekli bu organizasyonu genişletmiş, yenilemiş ve gelişen teknoloji ile desteklemiştir. Buna karşın, 2019 yılında yapılan III. Tarım ve Orman Şûrası "Orman Yangınlarıyla Mücadelede Yenilikçi Yaklaşımlar" grubu çalışma belgesinde orman yangınları ile mücadelenin en önemli bileşenlerinden olan arazöz ve yer ekiplerinin, orman yangın işçilerinin azalması nedeniyle yeterli sayıda oluşturulamaması, işçilerin yaş ortalamalarının yükselmiş olması nedeniyle fiziksel özelliklerinin yeterli olmaması, yangınlar konusunda uzmanlaşmış teknik personelin rotasyonla başka görev ve yerlere atanması nedeniyle orman

\footnotetext{
$\bowtie$ a Isparta Uygulamalı Bilimler Üniversitesi, Orman Fakültesi, Orman Mühendisliği Bölümü, Isparta

@ * Corresponding author (İletişim yazarı): mustafaavci@isparta.edu.tr

$\checkmark \quad$ Received (Geliş tarihi): 25.05.2021, Accepted (Kabul tarihi): 07.09.2021
}

Citation (Atıf): Avcı, M., Korkmaz, M., 2021. Türkiye'de orman yangını sorunu: Güncel bazı konular üzerine değerlendirmeler. Turkish Journal of Forestry, 22(3): 229-240. DOI: $10.18182 /$ tjf.942706 
yangınları konusunda kurumsal hafızanın zayıflamış olması OGM'nin zayıf yönleri olarak belirtilmiştir (OGM, 2019).

Orman yangınlarına yönelik ülkemizde yapılan bilimsel çalışmalar incelendiğinde; yangın verilerinin analizi (Küçükosmanoğlu, 1998; Bilgili vd., 2010; Bilgili, 2020), yanıcı madde ve yangın davranışı (Sağlam, 2002; Küçük, 2004; Sağlam vd., 2008; Dinç Durmaz, 2014; Bilgili ve Sağlam, 2003), yangın ekolojisi (Tavşanoğlu, 2009), yangınların dağılımı (Göktepe, 2011; Duran, 2014; Kurt, 2014) yangın riskinin haritalandırılması ve modellenmesi (Güney, 2013; Çoban ve Özdamar, 2014; Çoban ve Erdin, 2020; Baltacı ve Yıldırım, 2021), görünürlük analizi (Çoban ve Bereket, 2020), yangın kriminolojisi (Zile, 2018; Kavcin ve Kesler, 2019), eğitim ve toplum-orman kaynakları ilişkisinin sosyo-ekonomik boyutu (Coşgun, vd., 2010; Özden vd., 2012), organizasyon (Sağkaya, 2009), denetimli yakma ve yangına dirençli orman kurma teknikleri (Neyişçi vd., 1999; Neyişçi vd., 2002) konularının ele alındığ1 görülmektedir. Bu çalışmanın amacı, ülkemizdeki orman yangınlarının sayı ve alansal olarak değişimi ile sebeplerini analiz etmek, aynı zamanda son yıllarda üzerinde çeşitli tartışmalara konu olan hususlarda uzman görüşleri yardımıyla bir değerlendirme yaparak sorunların çözümüne katkısı olacağı düşünülen bazı öneriler getirebilmektir.

\section{Materyal ve yöntem}

Çalışma kapsamında ilk olarak OGM'nin geçmiş yıllara ait yangın verileri, Yangın Değerlendirme Raporları ve Yangın Eylem Planlarından yararlanılmıştır. Ardından orman yangınları konusunda güncel bazı konuların değerlendirilmesi için uzun yıllar yangına hassas bölgelerde görev yapmış, önleme ve mücadele çalışmalarına idari ve teknik ölçekte önemli katkılar sağlamış, konusunda tecrübeli, emekli veya halen aktif çalışan ve meslekte farklı kademelerde en az 20 yıl süreyle görev yapmış meslektaşlarımız ile değerlendirmeler yapılmıştır (Çizelge 1).

Konunun geniş bir çerçevede ortaya konulabilmesi için 11 adet sorudan oluşan mülakat formları hazırlanmıştır. Yöneltilen sorular ve yanıtlar ile öğrenilmesi hedeflenen konular; (1) Orman yangınlarının sayısal olarak son yıllarda artmasının nedenleri, (2) Orman yangınlarıyla mücadelede hava araçlarının organizasyonu, gerekliliği ve etkinliği, (3) Orman yangınlarının önlenmesi amacıyla yapılan mevcut faaliyetlerin yeterliliği, (4) Orman yangınlarında yanan alan miktarının belirlenmesi, (5) Sebebi bilinmeyen yangınların sayısının giderek artmasının nedenleri, (6) Orman yangınlarının sebeplerinin tespiti için öneriler (7) Orman yangınlarıyla mücadelede başarı göstergeleri, (8) Orman yangınlarının sebepleri-yöresellik değerlendirmesi, (9) Orman yangınları-rekreasyonel etkinlikler ilişkisi, (10) Orman yangınları ile mücadelede yapılan harcamaların değerlendirilmesi, (11) Toplumun orman yangınları ile ilgili bilgi ve bilinç düzeyinin geliştirilebilmesi için öneriler şeklinde sıralanmaktadır. Bu kapsamda 28 uzman e-posta ile mülakat formlarını doldurmaları için davet edilmiştir. Yapılan davete 22 uzman tarafindan yanıt verilmiş ve bu uzmanların mülakat formları değerlendirmeye alınmış olup geri dönüş oranı \%81,5 olarak gerçekleşmiştir. Bu oran, ilgili yazın incelendiğinde yeterli görülmektedir (Nulty, 2008). Elde edilen bilgiler her konu başlığı altında ayrı ayrı birleştirilerek değerlendirilmiş ve yorumlanmıştır.

\begin{tabular}{lrc}
\multicolumn{3}{l}{ Çizelge 1. Uzmanların profili } \\
\hline \multicolumn{3}{c}{ Sayı } \\
\hline Görev y1lı & & \\
\hline $20-25$ yıl & 5 & 22,7 \\
$26-30$ yıl & 5 & 22,7 \\
$>30$ y1l & 12 & 54,6 \\
\hline Çalışma durumu & Say1 & $\%$ \\
\hline Aktif çalışan & 19 & 86,4 \\
Emekli & 3 & 13,6 \\
\hline
\end{tabular}

\section{Bulgular ve tartışma}

Türkiye'de 1937 yılından 2020 yılı sonuna kadar kayıtlara geçen yangın sayısı 114.941 olup uzun yıllar ortalaması 1.369 adet/yıl'dır. 2011-2020 yıllarını kapsayan son on y1llık dönemde ise yıllık ortalama sayı 2.631'dir. Yıllık meydana gelen yangın sayılarında küçük dalgalanmalar olmakla birlikte son 50 yılda sürekli bir artış eğilimi görülmektedir (Şekil 1). En fazla yangın çıkan üç yıl sirasiyla 2013 (3755 adet), 2020 (3399 adet) ve 1994 (3239 adet)'tür. Orman yangınlarıyla mücadeleye ek olarak her y1l hemen hemen orman yangını sayısına yakın zirai alan yangınına da müdahale edilmekte olup bu sayı 2020 yılı için 3.007'dir (OGM, 2021).

1937 yılından 2020 yılı sonuna kadar olan dönemde 1.711.973 ha saha yanmış, yıllık ortalama yanan saha miktarı 20.380 ha ve birim yangın başına düşen saha miktarı ise 14,9 ha olmuştur. 2011-2020 yıllarını kapsayan son 10 yıllık dönemde ise toplam 90.955 ha saha yanmış, yıllık ortalama kayıp miktarı 9.096 ha, yangın başına isabet eden saha 3,45 ha olmuştur. Yanan alan miktarı son on yılda yangın sayısının artmasına rağmen uzun yıllar ortalamasının yarısına kadar çekilebilmiştir. 2020 yılında yangın başına düşen zarar gören alan miktarı 6,17 ha olarak gerçekleşmiştir (OGM, 2021). OGM Stratejik Planı (20192023)'nda 2023 y1lı için yangın başına düşen alan miktarının 2,2 ha seviyesine düşürülmesi hedeflenmektedir (OGM, 2018).

\subsection{Orman yanginlarinın sebepleri}

Türkiye'de 2001-2020 dönemi orman yangınlarının sebepleri incelendiğinde yangınların \%40'ının sebebinin belirlenemediği, \%35,3'ünün ihmal-dikkatsizlik, \%11,8'inin yıldırım, \%8,0'ının kasıt ve \%4,9'unun kaza olduğu anlaşılmaktadır. $\mathrm{Bu}$ verilerin 2001-2010 dönemi için sirasiyla $\% 20,3, \% 51,8, \% 12,2, \% 11,0$ ve $\% 4,7,2011-2020$ döneminde ise $\% 46,8, \% 31,0, \% 11,5, \% 5,6$ ve $\% 5,1$ olduğu (Şekil 2) görülmektedir (OGM, 2021).

Türkiye'de 2001-2020 dönemi orman yangınlarının sebeplerinin y1llara göre değişimi değerlendirildiğinde dikkat çeken en önemli iki değişim ihmal ve dikkatsizlik kaynaklı yangınlarda görülen düşüş ve sebebi bilinmeyen yangın sayılarındaki önemli artıştır. Önceki dönemlerde tüm yangınların yaklaşık \%30'unun sebebi bilinemezken son yıllarda bu oran \%50 seviyesine çıkmıştır. Örneğin; bu yangınların oranı 2013 yılında \%48,4, 2016 yılında $\% 54,3$, 2017 yılında \%53,2, 2019 yılında \%48,7 ve 2020 yılında ise $\% 54,7$ oranında gerçekleşmiştir (Şekil 3). Bu durum orman yangınlarının daha çıkmadan önlenebilmesi aşamasında önemli bir sorun olarak karşımızda durmaktadır. Yangınların çıkış sebepleri bilinemediği takdirde bunu önlemeye yönelik alınabilecek önlemlerin yeterli olmayacağı açıktır. Aynı zamanda bu oranın son yıllardaki artışının ayrıntılı bir şekilde sorgulanması gereklidir. 
Yangına ulaşım süresi (2020 yılı için 12 dk.) kısalmışken (OGM, 2021) ve teknolojik olanaklara sahiplilik düzeyi artmışken bu oranın kötüye doğru seyri düşündürücüdür.

Sebebi belirlenen yangın sayıları içinde en yüksek oranda olan ihmal-dikkatsizlik, tali sebepler olarak anız, çöplük, avcılık, çoban ateşi, sigara, piknik ve diğer şeklinde ayrılmaktadır. Şekil 4 incelendiğinde, bu sebepler içinde anız kaynaklı yangınların önemli bir yer tuttuğu görülmektedir. Bunun yanında dikkat çeken diğer bir durum ise sigara kaynaklı yangınlarda görülen önemli azalmadır. Ancak ihmal-dikkatsizlik ana başlığı altında bulunmakla beraber incelenen dönemde bu yangınların da \%44'ünün tali sebebinin "diğer" olarak yazıldığı, yeterli bir tespitin yapılamadığı anlaşılmaktadır. 2020 yılı yangınları incelendiğinde ihmal ve dikkatsizlik sonucu çıkan yangınların \%21'i anız, \%5'i çoban ateşi, \%4'ü sigara nedeniyle çıkmış olup \%3'ü ise çöplük yangınlarıdır (OGM, 2021). Benzer şekilde Avcı vd. (2009), 1998-2008 yıllarını kapsayan dönemde çıkan 85.865 adet yangının sebeplerini inceledikleri çalışmalarında yangına neden olan en önemli etmenin ihmal ve dikkatsizlik olduğunu, yıldırım kaynaklı yangınların artış eğilimi gösterdiğini ve sebebi bilinmeyen yangınların sayısının gitgide arttığını belirtmişlerdir.

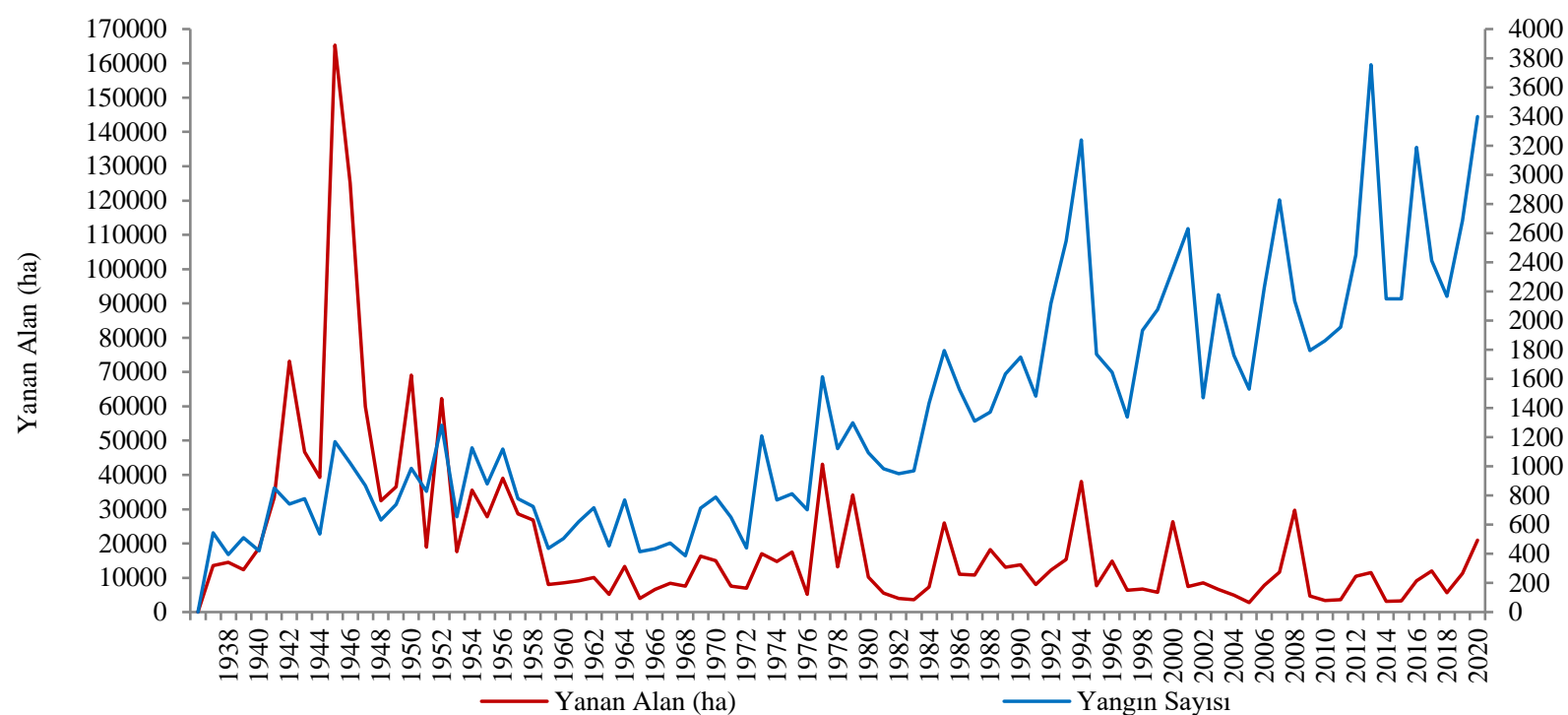

Şekil 1. Türkiye'de 1937-2020 dönemi orman yangını sayıları ve yanan alan miktarları

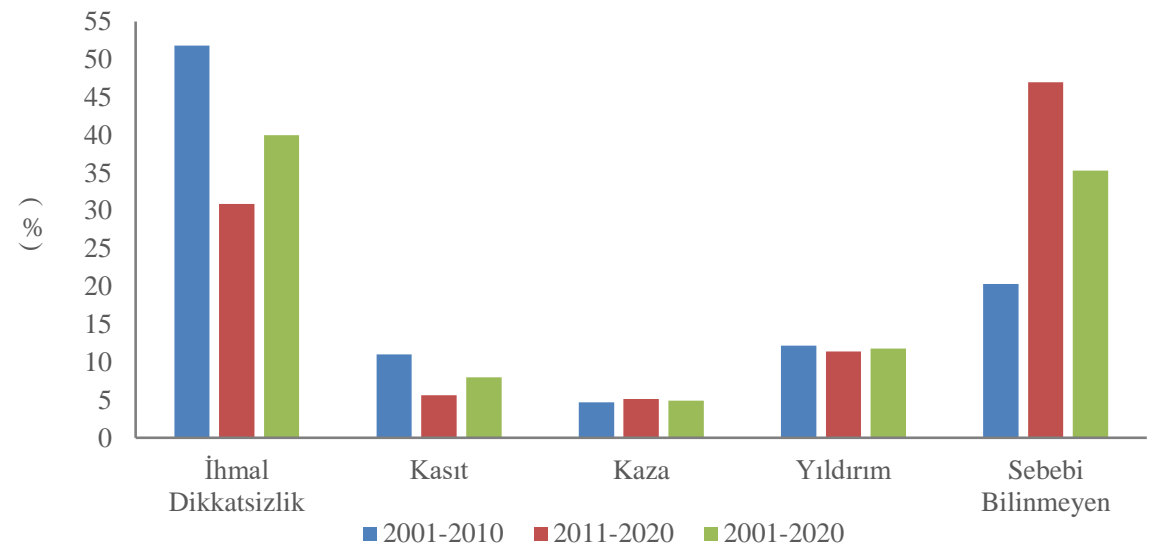

Şekil 2. Türkiye'de 2001-2020 dönemi orman yangınlarının sebepleri 


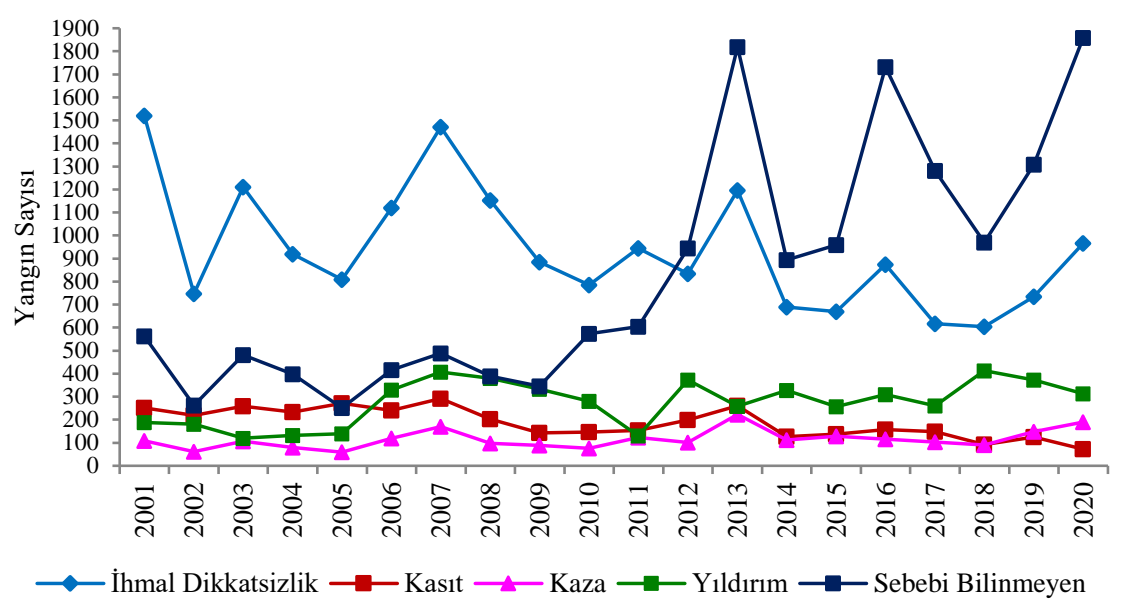

Şekil 3. Türkiye'de 2001-2020 dönemi orman yangınlarının sebeplerinin yıllara göre değişimi

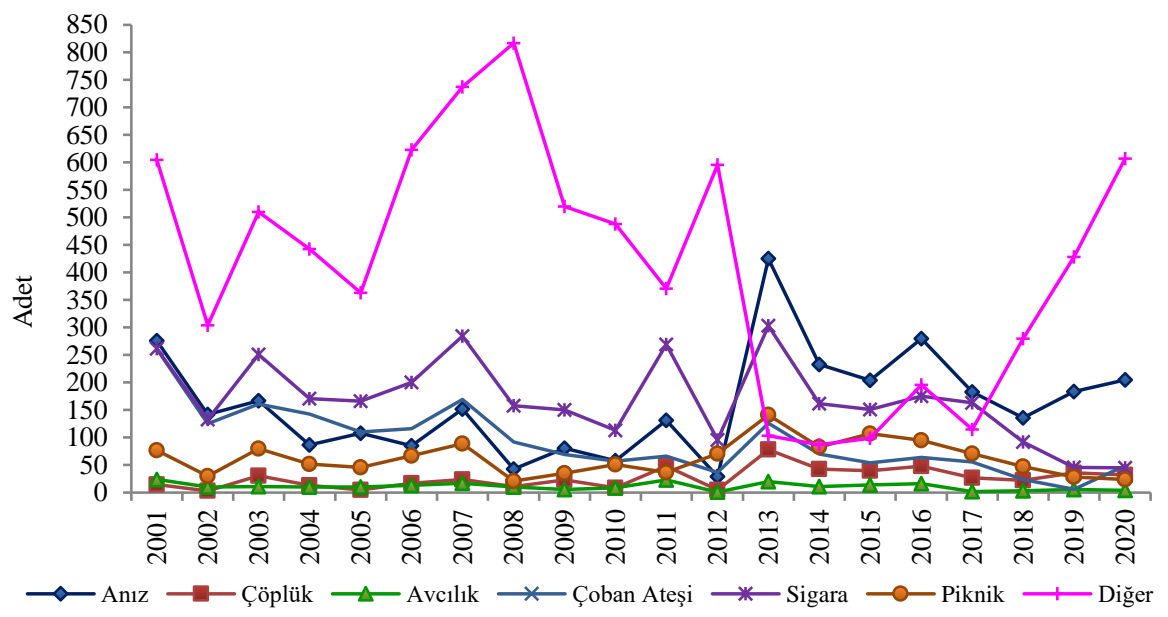

Şekil 4. Türkiye'de 2001-2020 dönemi ihmal-dikkatsizlik yangınların tali sebeplere dağılımı

\subsubsection{Yangın sayılarında son yıllardaki artışın nedenleri}

Türkiye'de çıkan orman yangın sayıları incelendiğinde daha önce de belirtildiği üzere son yıllarda bir artış olduğu gözlenmektedir. Özellikle 2020 y1lında son on yıllık ortalamaya göre \%35 oranında bir artış meydana gelmiştir. $\mathrm{Bu}$ konuda görüşleri sorulan uzmanların verdikleri yanıtlara göre orman yangınlarının son yıllarda sayısal olarak artışı üzerinde birçok faktörün etkili olduğu görülmekte olup bu kapsamda uzmanların görüşleri Çizelge 2'de gösterilmiştir.

Uzman görüşlerine göre $(\% 54,5)$ orman yangın sayılarının son yıllarda artışındaki en önemli neden, orman içi ve bitişiğindeki nüfus hareketliliğinin artışıdır. Son yıllara ait kayıtlara göre yangınların \%88'inin insan kaynaklı olduğu düşünülürse bu beklenen bir durumdur. Örneğin, yangına hassas olan Ege ve Akdeniz Bölgelerinde nüfus, Anadolu'dan bu bölgelere olan yoğun göç hareketi ile son yıllarda hızlı bir şekilde artmaktadır. Buna ek olarak yaz aylarında bu bölgelerde turizm etkinlikleri de yoğun bir şekilde yapılmaktadır. Örneğin bir çalışmada Bodrum sahil bölgesi için 2015 yılı verilerine göre yaz nüfusunun kış nüfusuna göre $\% 728$ oranında artış gösterdiği tespit edilmiştir (Öner vd., 2019). Ayrıca orman içerisinde verilen maden, enerji, turistik tesis vb. izinler orman yangınlarının artmasına ve söndürme çalışmalarının daha da karmaşıklaşmasına yol açmaktadır. Bu durum aynı zamanda sınır coğrafyasını değişime uğratmıştır. Örneğin 2008-2019 yılları arasında 10 hektardan küçük parça sayısı \%118 oranında artış göstermiştir (OGM, 2009; 2020).

Turizm ve rekreasyonel etkinliklere (piknik vb.) olan talep artışı ve bu kapsamda yakılan kontrolsüz ateşler ve atılan sigara izmaritleri ve rekreasyon alanları dışındaki ormanlarda izinsiz olarak piknik yapılması, bu hususta etkili olan diğer etmenlerdir. Benzer şekilde Bilgili (2020), turizmin artan bir hızla gelişmesi ve rekreasyonel amaçlı orman alanlarındaki kullanımın artması nedeniyle ihmal ve dikkatsizlik sonucu çıkan yangınlarda önemli bir artış olduğuna dikkat çekmektedir. Halkın eğlenme ve dinlenme amaçlarına yönelik rekreasyon alanlarını uzmanların \%59,1'i yeterli görürken, yetersiz olduğunu belirten uzmanlar gerek yer seçimi gerekse alt yapı donatıları bakımından yangın riski değerlendirilerek bu alanların artırılmasını önermiştir. 
Çizelge 2. Orman yangınlarının sayısal olarak son yıllarda artmasının nedenlerine ilişkin görüşlerin dağılımı*

\begin{tabular}{|c|c|c|}
\hline Görüşler & Say1 & $\%$ \\
\hline Nüfusun ve orman içi ve bitişiğindeki nüfus hareketliliğinin artışı ile ormanda verilen izinler & 12 & 54,5 \\
\hline Turizm ve rekreasyonel taleplerin artışı & 11 & 50,0 \\
\hline Hava hallerindeki ciddi dalgalanmalar, sıcaklıkların artışı, yağışların azalması ve orta/uzun süreli kuraklıklar & 8 & 36,4 \\
\hline Toplumun orman yangınlarına yönelik bilinç düzeyinin yeterli olmaması & 7 & 31,8 \\
\hline Bahçe ve sera artıklarının temizliği ve anız yakma & 7 & 31,8 \\
\hline Enerji nakil hatlarının yıpranmış olması ve tamir-bakımlarının yeterince yapılmaması & 7 & 31,8 \\
\hline Terör & 6 & 27,3 \\
\hline Yangınların geçmiş yıllara göre daha fazla kayıt altına alınması & 3 & 13,6 \\
\hline
\end{tabular}

*Her bir uzman birden fazla yanıt vermiştir.

Son yıllardaki hava hallerindeki ciddi dalgalanmalar, sıcaklığın artması, yağışın azalması ve orta/uzun süreli kuraklıklar sonucu yanıcı maddenin neminin düşmesinin yanmayı kolaylaştırarak orman yangın sayılarının artışında etkili olduğu görüşü üçüncü sırada yer almaktadır $(\% 36,4)$. Genel iklim değişikliklerinin etkisiyle yaz mevsiminin daha sıcak ve kurak geçmesi ve hava sıcaklıklarının mevsim normalleri üzerinde seyretmesi, yangınların sayısal olarak artması üzerinde etkisini göstermektedir. Türkiye son yıllarda iklim değişikliğinin sonucu olarak daha sıcak ve kurak bir dönem geçirmektedir. Dünyada 2016 yılı en sıcak yıl olarak kayıtlara geçmiş olup 2020 yılı ise ölçümlenen en sıcak ikinci yıl olmuştur. Bunu sırasıyla 2019, 2017, 2018, 2015, 2010, 2014, 2005 ve 2013 yılları izlemiştir. Meteoroloji Genel Müdürlüğü (MGM) verilerine göre, Türkiye'de uzun yıllar sonbahar (eylül, ekim, kasım) mevsimi ortalama sicaklığı $14,8{ }^{\circ} \mathrm{C}$ olarak ölçülmüşsen, 2020 yılının sonbaharında ise ortalama sicaklık $2,5{ }^{\circ} \mathrm{C}$ artarak $17,3{ }^{\circ} \mathrm{C}$ 'ye yükselmiştir (MGM, 2021). Türkiye'de yağışlarda genel bir azalma (normalden daha kurak), yüzey hava sıcaklıklarında belirgin bir artış (hava normalinden daha sıcak ve çok sıcak), yüzey hava bağıl neminde önemli azalma (hava normalinden daha kuru) ve üst toprak $(0-7 \mathrm{~cm})$ neminde azalma (normalinden daha kurak ve çok kurak) gerçekleşmiştir. Bir yıllık verilere baktığımızda, yani 12 aylık kuraklık indis analizleri incelendiğinde Orta ve Doğu Karadeniz'de bile bir kuraklık söz konusudur (Türkeş, 2020).

MGM tarafindan yayınlanan 2020 yılının, 3, 6, 9 ve 12 aylık meteorolojik kuraklık analiz haritaları incelendiğinde, Türkiye'nin özellikle yılın ikinci yarısında beklenen yağışları alamadığı, hatta önemli bir bölümünün olağanüstü ve şiddetli kurak koşullar yaşadığı görülmektedir. Bu ekstrem koşullar nedeniyle, 2020 yılında yanan alan itibariyle çok sayıda önemli yangın gerçekleşmiştir. Bunlar; Hatay/Karaçay (3.594 ha), Adana/Kozan (1.870 ha), İzmir/Gaziemir (1.455 ha), Kastamonu/Taşköprü (1.323 ha), Manisa/Ahmetli (864 ha), Manisa/Gördes (790 ha), Çanakkale/Anafartalar (783 ha), Hatay/Belen (669 ha), Ankara/Nallıhan (663 ha), Adana/Pozantı (652 ha), Hatay/İskenderun (617 ha) ve İzmir/Gaziemir (430 ha) yangınları olup daha önceki yıllarda bu miktarlarda yangınlar bir sezonda gerçekleşmemiştir (OGM, 2021).

2020 y1lı, orman yangınlarının sadece Akdeniz, Ege ve kısmen Marmara Bölgesine ait bir tehdit olmadığını Karadeniz ve İç Anadolu Bölgelerinin de bu tehdit altında olduğunu göstermesi bakımından önemli bir yıl olmuştur. Örneğin Kastamonu Orman Bölge Müdürlüğü, yanan alan bakımından Muğla, Antalya ve Mersin Orman Bölge Müdürlüklerini geride bırakarak dördüncü sırada yer almıştır. Yangına hassas olarak kabul edilen bölgeler dışında çıkan önemli yangınlar; Kastamonu/Taşköprü (1323 ha), Ankara/Nallıhan (663 ha), Sinop/Boyabat (361 ha), Çorum/Karg1 (241 ha), Edirne/Meriç (142 ha),
Bolu/Dörtdivan (132 ha), Kütahya/Emet (76 ha) ve Çorum/İskilip (66 ha) yangınlanıdır (OGM, 2021).

Meteorolojik verilerin bundan sonra da kuraklık yönünde seyrinin devam etmesi durumunda yangına hassas alanların giderek genişleyeceği anlaşılmaktadır. Türkeş ve Altan (2012), Muğla'da 2008 yılında çıkan yangınların kuraklık indisleri ile çözümlenmesine yönelik yaptıkları çalışmalarında bu konuya dikkat çekmiş ve mevcut egemen iklim özellikleri ile gözlenen ve kestirilen iklim değişikliği ve değişkenlikleri göz önünde bulundurularak yöneticilerin bugünden gelecekte oluşabilecek afetler konusunda önlem almaları ve özelde orman yangınlarının önlenmesine yönelik ulusal, bölgesel ve yöresel çözüm önerilerinin geliştirilmesi gerektiğini vurgulamıştır. Calda vd. (2020), iklim değişikliğinin Akdeniz Havzası orman yangınlarına etkisinin son yıllarda giderek arttığını, bu sorunun temelinde iklim değişikliği ile birlikte Akdeniz ikliminin hâkim olduğu bölgelerde yazların daha sıcak ve kurak geçmeye başlamasının olduğunu ve böylelikle orman yangınlarının sayısının artmasına neden olduğunu bildirmiştir.

Orman yangınları konusunda toplumda artan bilgi düzeyine rağmen bilinç düzeyinin yeterli olmaması, insanların dikkatsizliği, bilinçsiz ateş yakmaları, orman yangınlarının önlenmesi hususlarında genel olarak toplumsal duyarlılığı yetersiz olması da uzmanların \%31,8'i tarafindan son yıllarda yangın sayısındaki artışın nedenleri olarak ifade edilmiştir.

Günümüzde orman bitişiği yerleşimlerde gerekli tedbirler alınmamasından dolayı çıkan ve ormana sirayet eden yangın sayısında artış gözlenmektedir. Örneğin 2017 yılında kırsal alan yangın sayısı 2.541 iken bu sayı 2020 yılında 3.007 olarak gerçekleşmiştir (OGM, 2021). Tarla, bağ, bahçe ve sera artıklarının temizlik amaçlı yakılması önüne geçilemeyen bir sorundur. Özellikle anızdan ve tarımsal arazi temizliğinden dolayı çıkan yangınların sayısının daha önce de belirtildiği üzere geçmiş yıllar ile karşılaştırıldığında artma eğiliminde olduğu anlaşılmaktadır. Anız yangınları, ince ve kuru yanıcı materyal nedeniyle hızlı ilerlemesi ve cephesinin geniş olması nedeniyle kısa zamanda ormanllk alanlara sirayet ederek önemli bir orman yangınına dönüşebilmektedir. Örneğin 27 Temmuz 1994 tarihinde Çanakkale/Eceabat'ta anız kaynaklı çıkan orman yangınında 4.049 ha alan zarar görmüştür (OMO, 1994). Anız yakmanın yasaklanması bu sorunun çözümü için yeterli olmayıp anız yakmayı gerekli kılan nedenlerin irdelenerek anız yakmadan bu sorunu ortadan kaldırabilecek çözümlerin bulunması ve uygulanması önem arz etmektedir (Neyişçi, 1994).

Yangın sezonunda kuvvetli (özellikle Akdeniz ve Ege Bölgelerinde poyraz/fön rüzgârı, Karadeniz Bölgesinde kıble ve lodos) rüzgârların olduğu günlerde, orman içerisinden geçen enerji nakil hatları (ENH)'nda meydana gelen arklar, yaz aylarında aşırı enerji gereksinimi nedeniyle hatlardan yüksek oranda enerji çekilmesi nedeniyle trafo 
merkezinde meydana gelen patlamalar ve iletim hatlarının kopması, ENH'lerin çoğunluğunun yıllar boyunca yıpranmış olması ve tamir-bakımlarının yeterince yapılmaması sonucu gerçekleşen yangınlar sayısal olarak yüksek olmamakla birlikte alansal olarak önemli etkiye sahiptir. Örneğin 2020 yılında ENH'lerden kaynaklanan yangınların sayısal olarak tüm yangınlara oranı \%3,91 iken yanan alan bakımından ise \%16,68'dir (OGM, 2021). Türkiye'nin en büyük yangınlarından biri olan ve 31 Temmuz 2008 tarihinde Taşağıl Orman İşletme Müdürlüğü Karabük Orman İşletme Şefliği Pelitdibi mevkiinde başlayan ve 15.795 ha orman alanını etkileyen yangının nedeni, ENH kaynaklıdır.

Orman yangınlarının sayıca artışında terör amaçlı yakmaların da etkili olduğu bilinmektedir. Ülkemizde 20012020 döneminde meydana gelen 62 adet terör kaynaklı yangından 47 adedinin 2015 yılı ve sonrasında çıktığ belirlenmiştir (OGM, 2021).

Orman yangınlarının son yıllardaki artışının nedenlerinden birisi de uzman görüşlerine göre düşük düzeyde önemli görülen yangınların geçmiş yıllara göre daha fazla kayıt altına alınmasıdır. Bu görüşe katılım oranı $\% 13,6$ ile düşük düzeydedir.

\subsubsection{Kök sebeplerin belirlenmesi}

Kök sebep, bir sorunun altında yatan temel sebep veya sebepler bütünü olarak tanımlanabilir. Kök sebep analizi ise bir sorunun; yalnızca hata veya uygunsuzluk olarak tanımlanması yaklaşımından farklı olarak, sorunun neden ortaya çıktığını belirleme süreci olup (İSKİ, 2021) meydana gelen hatalarda, hataların çıkış noktasındaki asıl sebebin ne olduğunun tespitine ve hataların tekrarlanmaması için alınacak tedbirlere yönelik çalışmaları kapsamaktadır (Kaya, 2017).

Orman yangınlarının yerel olarak dağılımı ve çıkan yangınların sebepleri bakımından belli yerlerde yoğunlaşmaların olduğu, bu yönleriyle yangınların homojenlik göstermediği hususunda yapılmış çeşitli çalışmalar bulunmaktadır (Göktepe, 2011; Kurt, 2014; Duran, 2014). Zile (2018) tarafindan Adana ve Mersin illerinde 23 Temmuz 2011 ile 12 Ağustos 2013 tarihleri arasında meydana gelmiş ENH'lerden kaynaklı sekiz adet orman yangınına ait gözlemsel ve kayıtların incelenmesi ile bu yangınlardaki kusurların neler olduğu tespit edilerek yangınların tekrar çıkmasının önlenebileceği belirtilerek kök sebeplerin belirlenmesinin önemi vurgulanmıştır. Bu bölümde orman yangınlarına neden olan kök sebeplerin araştırılması gerekliliği konusundaki görüşlere ve değerlendirmelere yer verilmiştir.

Uzmanlara yöneltilen "Orman yangınları ile ilgili tutulan kayıtların daha kapsamlı analiz edilmesiyle (örneğin yangınların çıkış yerleri ve sebepleri) yöresel olarak bazı önlemlerin alınabilmesi mümkün müdür?" sorusuna verilen yanıtlar değerlendirildiğinde, tüm uzmanlar tarafindan evet yanıtı verilmiş olup orman yangınlarına yol açan kök sebeplerin yöresel düzeyde incelenmesinin, orman yangınlarını önleme çalışmalarına çok yüksek düzeyde katkı yapacağ belirlenmiştir.

Her yörenin kendine özgü ekonomik, sosyal, kültürel ve ekolojik koşulları vardır. Özellikle yangın çıkış sebepleri üzerine yoğunlaşmak, daha yangın çıkmadan alınması gereken önlemler açısından önemli bilgiler sağlayabilecektir. Tarla açma, işgal, yaylacılık, otlatma, kaçakçılık vb. birçok konuda her yörede farklı insan davranışları vardır. Bunlara karşı idarenin ve insanların birbirlerine yönelik tavırları da farklılaşmaktadır. $\mathrm{Bu}$ karşılıklı davranışların ormana zarar vermemesi için şeffaf, tarafsız ve adil yönetim önemlidir. Ayrıca caydırıcılıkla ilgili teknik ve hukuki birçok yerel tedbir de söz konusu olacaktır. Yani ormancılık etkinliklerinin genelinde olduğu gibi yangınlarla ilgili çözümlerde de yöresellik önemli bir husustur. $\mathrm{Bu}$ da her yöre için farklı önlem ve yangınla mücadele yöntem ve stratejileri gerektirir. Diğer bir deyişle hassas bölgelerde yangına karşı alınacak farklı önlemlerin belirlenmesi ve uygulanması, başarı için önemlidir. Yangın başlama noktası ve yangın sebepleri sağlıklı olarak belirlenebilirse, hedef kitle ve hedef alan (olası yangın başlama yerleri) için yöresel ölçekte alınacak önlemler etkili olacaktır.

Orman Bölge Müdürlükleri 2012-2015 döneminde değerlendirildiğinde tali sebeplere göre ilk sırada yer alan bölgeler ve oranları şu şekildedir; anız (İzmir \%26), çöplük (İzmir \%17), avcıllk (Mersin \%32), çoban ateşi (İzmir \%29), sigara (İzmir \%33), piknik (İstanbul \%42), terör (Kahramanmaraş \%33), kundaklama (Muğla \%46), açma (Amasya \%22), ENH (Mersin \%13), ve yıldırım (Muğla \%32). Benzer şekilde Antalya Orman Bölge Müdürlüğünde çıkan yangınlar, 2014-2018 dönemi 13 adet Orman İşletme Müdürlüğü bakımından değerlendirildiğinde, yangın sebepleri işletmelere göre önemli farklılık göstermekte olup sebeplerin dağılımı; anız (Alanya \%26), sigara (Antalya \%28), piknik (Manavgat \%32), kundaklama (Antalya \%22), ENH (Antalya \%19), meçhul (Antalya \%28) ve yıldırım (Taşağıl \%19) şeklindedir. Bu durumu Manavgat Orman İşletme Müdürlüğüne bağlı 4 Orman İşletme Şefliği açısından 2014-2018 dönemi için incelediğimizde ise; anız (Şelale \%80,0), sigara (Şelale \%75), piknik (Şelale \%84), kundaklama (Şelale \%43), ENH (Yaylaalan \%50) ve yıldırım (Yaylaalan \%77) sebepleri görülmektedir (OGM, 2021). Bu değerlendirmelere göre gerek bölge gerekse işletme ve şeflikler itibariyle yangın sebeplerinin önemli oranda değişiklik gösterdiği anlaşılmaktadır. Ege Bölgesi ile Akdeniz Bölgesi arasındaki farklılıkların büyük bölümü topoğrafya ile açıklanabilirken Çanakkale ve Muğla'nın belli kesimlerinde rüzgâr daha belirleyici olabilmektedir. Ayrıca Antalya Orman Bölge Müdürlüğünde en çok yangın çıkan İşletme Müdürlükleri poyraz rüzgârlarına açık Serik ve Manavgat Orman İşletme Müdürlükleridir (Neyişçi, 1988). Bu nedenle orman yangınlarını önlemeye yönelik tedbirlerin daha küçük ölçekte düşünülmesinin daha doğru olacağı aşikârdır.

\subsection{Yangın sayısı ve yanan alan ilișkileri}

Orman yangınları sonucu zarar gören alan miktarı ile ilgili olarak yıllardır tartışmalar devam etmektedir. Bunlara 31 Temmuz 2008 tarihinde çıkan ve 15.795 ha alanın yandığı Antalya Taşağıl/Serik yangını ile 17 Ağustos 2019 tarihinde İzmir Gaziemir/Yeniköy'de çıkan ve 4.346 ha alanın yanmasına neden olan yangınlar örnek olarak gösterilebilir. Yanan alan miktarına ilişkin tartışmanın nedeni, orman kaynakları yöneticilerinin yanan alan miktarını düşük gösterip göstermedikleridir. Bu çalışma kapsamında uzman grubuna bu soru yöneltilmiş ve alınan yanıtlara göre bu konuda iki farklı görüşün ortaya çıtığı belirlenmiştir (Çizelge 3). 
Çizelge 3. Yanan alan miktarına yönelik görüşlerin dağılımı

\begin{tabular}{lcc}
\hline Görüşler & Sayı & $\%$ \\
\hline $\begin{array}{l}\text { Orman yangınlarında yanan alan miktarı olması } \\
\text { gerekenden daha az gösterilmektedir. }\end{array}$ & 12 & 54,6 \\
$\begin{array}{l}\text { Yanan alan miktarı doğru ve tam olarak } \\
\text { gösterilmektedir. }\end{array}$ & 10 & 45,4 \\
\hline
\end{tabular}

"Orman yangınlarında yanan alan miktarının az gösterildiği” görüşünü belirten uzmanlar $(\% 54,6)$, bazı bölgelerde ve bazı yöneticiler açısından bu sorunun olduğunu ve uzun yıllardan beri devam ettiğini belirtmektedir. Uzmanlara göre alan miktarının az gösterilmesinin çeşitli nedenleri bulunmaktadır. En önemlisi kamuoyu baskısıdır ki, çoğunlukla büyük yangınlarda alan miktarı düşük gösterilmektedir. Çünkü bu yangınlara basın mensupları yoğun ilgi göstermektedir. Haber niteliği taşıyan büyük yangınlarda basın mensuplarının büyük oranda ilgilendikleri en önemli konu, yanan alan miktarıdır. Diğer bir neden ise idare gözünde başarısız olarak addedilme korkusudur. Yani yangındaki alan miktarı yüksek olursa yangın söndürme ekibinin söndürmede başarısız olarak değerlendirileceği düşüncesidir ki, bunun nedeni yangınların başarı/başarısızlığında yanan alan miktarının en önemli gösterge olarak değerlendirilmesindeki yanlış inanıştır. $\mathrm{Bu}$ konuda detaylı açıklamalara "başarı göstergeleri" bölümünde yer verilmiştir.

İkinci görüş, yanan alan miktarının doğru ve tam olarak gösterildiği $(\% 45,4)$ şeklindedir. Bu noktada tartışmalara neden olan farklılıkların, yanan sahalar içerisinde bulunan ve OT, bozuk maki, taşlık, kayalık vb. orman örtüsü bulunmayan alanların düşülmesinden kaynaklandığı bu görüş kapsamında belirtilmektedir. Ayrıca bu konuda belirtilen diğer bir görüş, özellikle büyüme eğiliminde olan ve haber niteliği taşıyarak basına yansıyan orman yangınları ile ilgilidir. $\mathrm{Bu}$ tür yangınlar devam ederken basın mensupları sürekli yetkililerden yanan alan miktarını almak istemektedir. Yani yangın açısından basının merak ettiği en önemli konu yanan alan miktarıdır. Bu kapsamda yangın devam ederken gerçek yanan alan miktarının ölçülememesi, yangının devam etmesinden dolayı alanın değişecek olması, kamuoyu baskısı ve/veya yöneticilerin kamuoyunda başarısız oldukları algısının oluşmasından duyulan endişe nedeniyle, basına düşük alan miktarının verildiği belirtilmektedir. $\mathrm{Bu}$ noktada yangın çıkış formunda yanan alan miktarı, belirtilen nedenlerden dolayı itidalli ve tedbirli olarak bildirilmektedir. Basın mensuplarının yanan alan ile ilgili olarak yönelttiği sorular, yangın kontrol altına alınıncaya kadar gündemdedir. Yanan alan miktarı, soğutma çalışmalarının bitiminden itibaren yapılan ölçümlerle netleşir ve resmileşir. Yani yangın çıkış formu ile söndürme formu arasında fark olup basının ilk formdaki alan miktarını kullanması sanki düşük bildiriliyormuş gibi bir algının ortaya çıkmasına neden olmaktadır.

Uzmanlar, meydana gelen her yanginda yanan alan miktarının (orman ve kırsal alan) doğru olarak bildirilmesinin önemine dikkat çekmektedirler. Yanan alan miktarını düşük belirtmenin önemli olumsuz sonuçları; toplumsal duyarlılığın yeterli düzeyde sağlanamaması, toplumun kuruma karşı güveninin sarsılması, amenajman plan verileriyle uyumsuzluk ve silvikültürel çalışmalarda öngörülen alan için tahsis edilen bütçenin yetersizliği olarak sıralanmaktadır. Yanan alanın az gösterilmesi, sorunu adeta küçültüp gerekli önlemlerin alınamamasına da neden olabilecek, yangınla mücadele eden çalışanların yaptıkları mücadeleyi de değersiz kılabilecektir. Ayrıca orman işletme şefleri yangın zararlarının belirlenmesinde yanan alanın az gösterilmesi sonucunda eksik tazminat hesaplanması ve şikâyet halinde sorumlu olmaları gibi sonuçlarla da karşılaşabilecektir.

\subsection{Orman yangınlarının sebepleri arasında "meçhul" yangınların oraninın gittikçe artması}

Orman yangınlarının sebepleri incelendiğinde daha önce de belirtildiği üzere yarısından fazlasının meçhul olarak kayıtlara geçtiği görülmektedir. Bunun nedenlerine ilişkin uzman görüşlerinin değerlendirmeleri aşağıda sunulmuştur (Çizelge 4).

Birinci görüş (\%45,5); bu husustaki temel yaklaşımın en kolay ve sorun oluşturmayacak olması nedeniyle "meçhul" olarak zabıt tutulması ve yangın sicil fişinin bu şekilde düzenlenmesi şeklindedir.

Yangın araştırması profesyonel (kriminal) bir inceleme gerektirir. $\mathrm{Bu}$ incelemelerde amaç; yangının başlama yerinin, nedeninin, ateşleme kaynağının ve failin (sorumlusunun) belirlenmesidir (Kavcin ve Kesler, 2019). Uzmanların \%40,9'u kriminal inceleme konusunda uzman personel eksikliğini önemli bir neden olarak görmektedir.

Yangınların birçoğunun aslında nedeni ve faili belli olmasına rağmen ispatı mümkün olmadığından yani somut deliller bulunamadığından kayıtlara bu şekilde geçtiği bir diğer görüştür $(\% 40,9)$. Orman yangınlarına erken müdahale, yangının büyümemesi bakımından çok önemli olduğu için yangın mahalline giden ekiplerin önce yangının kontrol altına alınması sonra da söndürülmesine odaklanması bazen yangının ilk çıktığı noktadaki varsa delillerin de tamamen yanmasına ve yangının sebebinin tespit edilememesine neden olabilmektedir. Dolayisiyla yangınların sebeplerinin ve faillerinin belirlenememesi, belirlenenler hakkında da yeterli delilin mahkemeye sunulamamasından dolayı suçtan hüküm giyen sanık sayısı oldukça az olmakta, bu durum yangınlarla mücadelede zafiyet oluşturmaktadır. Ayrıca suçüstü durumu en zor eylemlerden olduğu için şahit bulunamamasından dolayı da yangınların bir bölümü meçhul olarak kayıtlara geçmektedir (\%22,7).

Bir diğer görüşe göre ise genel olarak yangınlarda cezaların ağır olması ve yüksek tazminatların çıkması köylerde gerçek faillerin gizlenmesinde bir etkendir. Bu görüşe katılım oranı \%9,1 ile düşük düzeydedir.

Çizelge 4. Orman yangınlarında "meçhul” yangınların sayısının gittikçe artmasının nedenlerine yönelik görüşlerin dağılımı*

\begin{tabular}{lrr}
\hline Görüşler & Say1 & $\%$ \\
\hline En kolay ve sorun oluşturmayacak olması & 10 & 45,5 \\
nedeniyle "meçhul” olarak zabıt tutulması & 9 & 40,9 \\
Kriminal inceleme konusunda uzman personel eksikliği & 9 & 40,9 \\
Delil yetersizliği & 5 & 22,7 \\
Suçüstü yapılamaması & 2 & 9,1 \\
\hline Faillerin gizlenmesi
\end{tabular}

*Bazı uzmanlar birden fazla yanit vermiştir. 
3.4. Orman yangınlar ile mücadelede hava araçları organizasyonu, araçların gerekliliği ve etkinliği

\subsubsection{Hava araçları organizasyonu uygulamaları}

Orman yangınları ile mücadele kapsamında OGM bünyesinde Havacılık Şube Müdürlüğü 1988 yılında kurulmuş olup günümüze kadar çeşitli nitelik ve su atma kapasitesine sahip uçak ve helikopterlerden faydalanılmaktadır. OGM'nin envanterinde Mayıs 2021 itibariyle 6 adet yönetim helikopteri ve 1 adet yönetim uçağ bulunmaktadır. Helikopterlerinden birer adedi İzmir, Muğla ve Antalya Orman Bölge Müdürlüklerinde, 3 helikopter ve yönetim uçağı Ankara'da konuşlanmıştır. Ayrıca aynı yıl içerisinde ilk kez gece uçuşu yapabilen helikopterler, orman yangınları ile mücadelede kullanılmıştır. Yangın organizasyonu içinde yer alan hava araçlarının payı ve önemi her yıl artmakta olup 2020 yılında 27 adet helikopter kiralanmış ve 5.760 saat uçuş gerçekleştirilmiştir. Ayrıca bir adet 10 tonluk su atma kapasitesine sahip helikopter, Muğla'da konuşlandırılmış ve toplam 202 saat görev yapmıştır. Bunun yanında 2 adet amfibik uçak kiralanmıştır. Hava araçlarının uçuşunun \%60’1 01 Ağustos-15 Eylül döneminde gerçekleşmiş ve tüm sezon için hava aracı ödemesi 338,6 milyon TL olmuştur. Bu kapsamda toplam mücadele harcamaları içinde hava araçlarının payı \%29,4 ile önemli düzeydedir.

\subsubsection{Hava araçlarının gerekliliği ve etkinliği}

Bu başlık altında hava araçlarının orman yangınlarıyla mücadele çalışmaları kapsamında gerekliliği ve etkinliğine yönelik uzman görüşleri değerlendirilmiş olup uzmanların tamamı hava araçlarının gerekliliği konusunda hemfikir kalmışlardır.

Orman yangını ihbarı alınır alınmaz ekiplerin hareket etmesi, hızlı bir şekilde yangın mahalline ulaşılması ve erken müdahalede bulunulabilmesi yangının büyümeden söndürülmesi açısından çok önemlidir. Hava araçlarının esas başarısı ilk müdahaleyi erken ve etkin yapabilme kabiliyetlerinde yatmaktadır. İlk müdahalenin başarısız olduğu durumlarda, hava araçları ancak hava hallerinin ve arazi şartlarının elverdiği ölçüde, yangınlarla mücadele amaciyla ve yangınların can ve mal kayıplarına sebep olabileceği alanlarda diğer yardımcı kaynak olarak kullanılırlar. Bununla birlikte karadan ulaşım imkânı bulunmayan bir yerde başlayan yangınlarda, havadan yangına en yakın güvenli bir noktaya ekip indirerek de etkili olmaktadırlar. Hava araçları orman yangınlarına müdahale eden kara ekiplerinin işlerini kolaylaştırmakta ve daha rahat ve güvenli bir çalışma ortamı oluşturmaktadır. Bazı uzak yangınlarda kara ekiplerinden daha önce yangına ulaşarak müdahale edebilmekte ve yangının ilerlemesini geciktirerek kontrol altına alacak ve soğutma çalışmalarını gerçekleştirecek olan yer ekiplerine avantaj sağlamaktadır. $\mathrm{Bu}$ kapsamda hava araçları, yer ekipleriyle koordineli çalışılması durumunda faydalı olabilmektedir. Tek başlarına şiddetli ve hızlı ilerleyen yangınları kontrol altına alabilme kabiliyetleri düşüktür. Ayrıca toplumun gözünde hızlı ve güçlü bir destek aracı olarak görüldüğü için psikolojik olarak da güven vermektedir.

Orman yangınlarıyla mücadelede en önemli unsur su kullanımıdır. Yangın bölgesine su ne kadar kısa sürede ulaştırılabilirse yangını kontrol altına alma süresi o kadar kısalabilmektedir. Ülke genelinde doğal kaynakların yanı sıra yaklaşık 4 km'de bir yapılan 4.150 adet havuz ve gölet ile helikopterlerin yangına su atma süreleri düşürülerek yangınlarla mücadele başarısında etkin rol oynamaları sağlanmaktadır. Komuta/idare helikopteri ile yangına müdahale daha etkin ve verimli şekilde yapılmaktadır. Ayrıca şiddetli rüzgâr ile büyüme eğilimi gösteren yangınlarda yangının atmalarla (spot) büyümesinin önlenmesi yönüyle de hava araçları etkilidir.

Hava araçları kapsamında faydalanılan uçak ve helikopterlerin karşılaştırılmasına yönelik görüşler aşağıda sunulmuştur.

Kapasite olarak uçakların daha fazla su alıp atmasına (812 ton) karşın, su alınabilecek kaynaklar kısıtlıdır. Helikopterler ise daha az su almasına (2,5-3,5 ton) rağmen orman içerisine yapılan 700-2.000 ton kapasiteli havuz ve göletlerden rahatlıkla su alıp yangın mahalline seri git-gel yaparak etkin müdahalede bulunabilmektedir. Hava araçlarında önemli olan su kaynağı ile yanan alan arasındaki yatay ve dikey mesafedir. Arazi yapısının kırıklı olduğu alanlarda helikopterlerin daha etkili olmasına karşın, uçakların yüksek irtifadan uçması nedeniyle atılan suyun hedefe isabeti ve etkisi nispeten daha düşüktür.

Uçakların helikopterlere göre kiralama maliyetlerinin yüksek olması, yangın yerindeki hareket kabiliyetinin topoğrafyadan dolayı daha sinırlı olması, su alımı yapabileceği kaynakların kısıtlı olması ve yangına çok alçalamaması olumsuzluklar olarak sıralanmaktadır. Buna karşın yangın yerine çok hızlı ulaşması, attığı su miktarının fazla olması, yangın hattını daha fazla kapatması nedeniyle özellikle denize yakın yerlerde çıkan yangınlarda, arazi yapısı da çalışmaya uygunsa uçaklardan faydalanılması önem arz etmektedir.

Yukarıdaki açıklamalardan hareketle her iki hava aracının etkili veya az etkili olduğu yerler ve durumlar olduğu için yangın amirinin uçak veya helikopter talebi dikkate alınarak merkezden uygun hava aracı sevk edilmesi en uygun yaklaşım olmalıdır.

\subsection{Yangın harcamalarına yönelik dĕgerlendirmeler}

Orman yangınları ile mücadele kapsamında gereğinden fazla harcama yapılıp yapılmadığı, orman yangınlarının ekonomisinin değerlendirilmesi bağlamında çok önemli olup bu konuda iki farklı görüş öne çıkmaktadır (Çizelge 5).

Birinci görüşe göre; orman yangınları ile mücadelede gereğinden fazla harcama yapıldığı belirtilmektedir. Bu görüşe uzmanların \%60'ından fazlası katılmaktadır. Orman yangınlarında ihbarla başlayan ve ilk müdahale ekiplerinin alana ulaşması ile devam eden süreçte, hava ve kara araçlarının konuşlandırılması, yakın bölgeler başta olmak üzere diğer bölgelerdeki yer ekiplerinin yönlendirilmesi gibi olağanüstü bir müdahale gerçekleştirilmektedir. Bazen büyüme ihtimali çok düşük olan orman yangınlarında bile hava araçlarının müdahale etmesi istenebilmektedir.

Çizelge 5. Orman yangınları ile mücadelede gereğinden fazla harcama yapılıp yapılmadığına ilişkin görüşler

\begin{tabular}{lcc}
\hline Görüşler & Sayı & $\%$ \\
\hline Gereğinden fazla harcama yapılmaktadır & 14 & 63,6 \\
Gereğinden fazla harcama yapılmamaktadır. & 8 & 36,4 \\
\hline
\end{tabular}


Bazı yangınlarda talep edilen hava veya kara araçlarına ihtiyaç bulunmadığı değerlendirilerek, araçlar yangın alanına ulaşmadan geri gönderilebilmektedir. Yani bazı yangınlarda gereksiz yerlere gereksiz güç transferi yapılabilmektedir. Bu durum, masrafları artırmanın yanında aynı zamanda başka alanlarda çıkabilecek ve tehlike yaratabilecek orman yangınları ile mücadele gücünün zayıflaması anlamına da gelebilmektedir. Büyüme ihtimalinin olduğu yangınlarda bu durum kesinlikle anlaşılabilirken, bu ihtimalin neredeyse olanaksız olduğu yangınlar için böyle kararların verilmesi yangın amiri ve müdahalede bulunan teknik ekibin yangın davranışlarına yönelik bilgi ve tecrübe düzeylerinin düşük olduğunu göstermektedir. Böyle durumlarda yangın amiri; rüzgâr yönü ve hızı, nem düzeyi, yangın davranışı, örtü/tepe yangını durumu, yanıcı maddenin durumu, ihtiyaç durumu vb. çok sayıda meteorolojik, topoğrafik, biyolojik, teknik ve yönetsel açıdan yangını değerlendirmeli ve buna göre takviye ihtiyacı olup olmadığına karar vermelidir. Bunun yanında kamuoyu baskısı da özellikle yoğun hava aracı kullanımına neden olmaktadır. Çünkü toplumun büyük bir bölümünde orman yangınlarının hava araçları tarafından söndürüldüğü düşüncesi hâkimdir.

İkinci görüş ise yangınların söndürülmesinde gereğinden fazla harcama yapılmadığını, özellikle büyük orman yangınlarında uçak ve helikopter başta olmak üzere hava ve kara araçları ile yoğun müdahalenin yapılmasının masrafları yükselttiğini belirten görüştür. Bunun yanında yangınla mücadelenin ormanların bekası için önemli olduğu belirtilerek harcama miktarının düşünülmemesi gerektiği, esas olanın yangının söndürülmesi olduğu görüşü de bulunmaktadır. Ülke ormanlarının parçalı ve yerleşim alanları ile iç içe olması, yangın ekiplerinin göreli olarak yaşlı olması ve teknik bilgi konusunda yeterli düzeyde bilgi sahibi olmamaları masrafları artıran diğer etmenlerdir.

Masrafların azaltılmasına yönelik olarak, orman yangınlarında helikopterlerin yanında uçak kullanımının da yaygınlaşmaya başlaması ve helikopterlerin kullanması için yapılan yangın havuzlarının uçaklar tarafindan kullanılamaması nedeniyle uçak yerine helikopter kiralanmasıyla maliyetin azaltılabileceği belirtilen görüşler arasındadir.

Bir başka öne çıkan konu, bütçenin büyük bir bölümünün yangın söndürme kapsamında kullanılması, yangınların önlenmesi ile ilgili yapılan çalışmaların toplam bütçe içerisindeki payının düşük düzeyde kalmasıdır. Bu bağlamda önleme ile ilgili faaliyetlere daha fazla bütçe ayrılmasının yangın sayısını azaltabileceğinin unutulmaması gerekliliği sıklıkla dile getirilmektedir. Benzer şekilde Bilgili (2020), orman idaresinin yangın politikalarını genelde yangınla mücadeleye yoğunlaştırdığını, ancak yangınların nedenlerini belirleme ve önleme hususunda yetersiz kaldığını ifade etmiştir. Aynı zamanda yangınlarla ilgili bilimsel çalışmaların da büyük ölçüde yangın davranışı ve ekolojisi hakkında yapıldığını, yangınların sosyal, ekonomik ve kültürel boyutunun ise hemen hemen hiç dikkate alınmadığını belirtmiştir.

\subsection{Orman yangınlarına ilişkin toplumsal algılara yönelik değerlendirmeler}

$\mathrm{Bu}$ başlık altında toplumsal algılara yönelik değerlendirmeler yapılmıştır. OGM tarafından 2014 yılında yaptırılan "Ormancılık Algı Araştırması"nın sonuçlarına göre; orman yangınlarını söndürmede en etkili kuruluş $\% 60,8$ ile itfaiye olarak görülürken, OGM \%25,6'lık bir oranda kalmıştır (OGM, 2014). Benzeri değerlendirmeler günümüzde de devam etmektedir. Uzmanlara göre bu algıların en önemli nedenleri;

- Özellikle büyük orman yangınlarında basın mensupları tarafından alınan görüntü ve röportajlarda yangının yakınında takviye amacıyla diğer kurum ve kuruluşların (itfaiye vb.) personel, araç ve ekipmanlarının bulunması,

- Bölge müdürlüğü düzeyinde orman yangınlarının seyri ile ilgili olarak basına sürekli ve güvenilir bilgi ve görüntülerin paylaşılması görevini yapacak basın müşavirliği veya benzeri birimlerin bulunmaması,

- Ulusal basında orman yangını uzmanı olmayan farklı kurum ve kuruluş yöneticileri veya çalışanları tarafından orman yangınları ile ilgili eksik veya yanlış bilgiler içeren röportaj vb. verilmesi,

- Toplumun orman yangınları başta olmak üzere çok sayıda ormanc1lık faaliyetine yönelik bilgi düzeyinin düşüklüğü ve ormancılık teşkilatının halkla ilişkiler çalışmalarının yetersizliği,

- Son yıllarda medya ve kamuoyu oluşturmaya yönelik projeler olumlu gelişmeler olarak nitelendirilmesine rağmen ormancılık örgütünün toplumda mevcut olan orman ve ağaç konusundaki duyarlılıktan yeterli düzeyde yararlanamaması şeklinde sıralanmaktadır.

\subsection{Orman yangınları ile mücadelede başarı göstergeleri}

Orman yangınları konusunda başarının veya başarısızlığın ölçümü çok önemlidir. OGM'nin 2019-2023 yılları arasını kapsayan Stratejik Planında 3 gösterge orman yangınlarını değerlendirmek için belirlenmiştir. 2023 yılı için belirlenen hedefler;

- İnsan kaynaklı yangın sayısının toplam yangın sayısına oran1 (\%84),

- Yangın başına düşen alan miktarı (2,2 ha),

- Yangına birinci derecede hassas bölgelerde ilk müdahale süresi (13 dk.) şeklinde sıralanmaktadır (OGM, 2018).

Bu konuda başarı durumunun ölçülmesi ile ilgili olarak göstergelerin neler olması gerektiği uzman grubuna sorulmuş ve alınan yanıtlara ilişkin değerlendirmeler aşağıda sunulmuştur.

Orman yangınları ile mücadelede başarı konusunda geçmişten günümüze iki gösterge her zaman ilk akla gelir; (1) yangın sayısı, (2) yanan alan miktarı. Uzman görüşlerine göre yangın sayısı, büyük oranda yangınların başarısını ölçmede kullanılması gereken en önemli göstergelerden biri olarak öne çıkmıştır. Gerek ülke gerekse bölge düzeyinde çıkan orman yangını sayısının azalması; toplumun bilinç düzeyinin artışı, denetimlerin yeterliliği veya ceza mekanizmalarının işe yaradığını göstermesi bakımından önem arz etmektedir.

Yanan alan miktarı, yangının başlamasından itibaren söndürme çalışmalarının tamamlanmasıyla ölçümler sonucu ortaya konulan bir göstergedir. Uzmanların tamamına yakını yanan alan miktarının; hava durumu, topoğrafya, kapalılık ve büyüme çağı, diri örtü durumu, yola olan mesafe, su kaynaklarına uzaklık, yangının çıkış saati vb. faktörler nedeniyle bir başarı göstergesi olarak kullanılmaması 
gerektiğini belirtmektedir. Görüldüğü üzere gerek arazi koşulları ve meteorolojik durum, gerekse meşcere yapıları gibi birçok etmenden dolayı orman yangınları büyüyebilmekte ve büyük alanlar yanabilmektedir. Orman yangınlarında başarı için yangın bölgesinin öncelikli olarak yangına hassasiyet derecesi önemlidir. Örneğin Trabzon'da 10 ha alanın yanmasına neden olan bir yangın, Muğla'da 100 ha'lık yangına eşdeğer olabilir. Çünkü şartlar ve yangına hassasiyet çok farklıdır. Bundan dolayı yanan alanın tek başına bir gösterge olarak alınmasının sakıncalı yanları bulunmaktadır.

Orman yangınlarının söndürülmesi sırasında kara ve hava araçlarından çok yoğun bir biçimde faydalanılmaktadır. Bu kapsamda özellikle hava araçlarının orman yangını söndürme çalışmalarına katılmasının maliyeti oldukça yüksektir. Bu noktada bazı orman yangınlarında gerekli olmasa da ihtiyaten hava araçlarının yönlendirildiği ve bu nedenle yangın söndürme maliyetlerinin çok yükseldiğgi, belirtilen görüşler arasındadır. $\mathrm{Bu}$ durumu ölçmek için önerilen gösterge; harcama miktarı/yanan alan şeklindedir. Ancak, bu gösterge ile müdahaleyi zorlaştıran ve/veya hava araçlarının kullanımını zorunlu kılan faktörler göz ardı edilebilecektir. Bu durum, birçok faktörün işin içine dahil edilmesini ve çoğul değerlendirmeyi gerektiren bir husustur.

Yangın başladıktan sonraki yani söndürme sürecini değerlendirmek için önerilen diğer göstergeler;

- İlk müdahale süresi,

- Kara ve hava araçlarının toplanma zamanı ve eşgüdümü şeklindedir.

Yukarıda belirtilen iki gösterge de yangına doğru ve zamanında müdahalenin ölçümü için önerilmiştir. $\mathrm{Bu}$ noktada ikinci gösterge kapsamında ise;

- Yangın amirinin ve ekibin yöreyi iyi tanıması: En kısa ulaşım yolları, su kaynaklarının bilinmesi vb.

- Teknik yeterlilik: Yol ağının yeterliliği, bakım durumu vb.

- Yangın ekibinin durumu: Uzman yangın işçisi çalıştırma durumu, ekibin profesyonel olup olmaması, ekip içi ilişkilerin durumu, ekip ruhu vb.

- Orman kaynaklarının yangınlara dayanıklılığı: Meşcere bakımları vb.

- Erken haber alma durumu: Alo 177, 112, yangın gözetleme kuleleri vb. alt göstergeler öne çıkmıştır.

Yukarıda görüldügü üzere uzmanlar tarafından çok sayıda gösterge önerilmiş̧ir. Orman yangınları mücadelede çok sayıda etmen etkili olmaktadır. $\mathrm{Bu}$ nedenle tüm yangınlarda mücadelenin başarısını ölçmek için kullanılabilecek standart bir gösterge setinin belirlenmesi hem güç hem de gerçekçi olmayacaktır. Bu bağlamda her bir yangının kendine has özellikleri ve etkileyen etmenler değerlendirilerek, belirlenecek göstergeler ile mücadele başarısının ölçümü doğru bir yaklaşım olabilecektir.

\section{Sonuç ve öneriler}

Türkiye'de orman yangınları ile mücadelede özellikle sayısal olarak yangınların azaltılmasına yönelik önleme tedbirleri ağırlıkta olmak üzere genel olarak mücadele hususunda belirlenen eksikliklerin giderilmesi ve daha başarılı olunabilmesi için uzmanlardan elde edilen bilgiler 1şığında ulaşılan sonuçlar ve öneriler aşağıda sunulmuştur.

- Halkla Iliş̧kiler: Orman yangınlarının sayısal olarak azaltılması ve çıkan yangınların nedenlerinin belirlenebilmesi için orman-halk ilişkilerinin oldukça önemli olduğu bilinmektedir. Sosyolojik yapı, ekonomik durum, kültür, eğitim seviyesi ve halkın ormandan beklentilerinde görülen farklılıklar halkla iyi bir iletişim kurulması hususunda yöresel olarak farklı yaklaşımlar ve politikaların üretilmesini gerektirmektedir. Yerel koşulların iyi bilinmesi, orman halk ilişkilerinin sağlıklı bir şekilde sürdürülmesi için önemlidir. Ormancılık örgütü yönetici ve çalışanlarının hedef kitle ile olan samimiyeti ve sağladığ güven hem yangın sayısının azalmasını hem de yangınların nedenlerinin ve faillerinin belirlenmesi açısından fayda sağlayabilecektir. Bununla birlikte OGM başta olmak üzere ormancılık ile ilgili kamu kurumları, orman fakülteleri, ormancılıkla ilgili sivil toplum kuruluşları ve meslek odası ormancılıkta halkla ilişkileri geliştirmek için daha etkin çalışmalar yapmalıdır.

- Bilinçlendirme eğitimi: Orman yangınlarının önlemesinde hedef kitle olarak görülen orman köylülerine ve ilköğretim çağındaki öğrencilere her yıl eğitimler verilmektedir. Ancak verilen bu eğitimlerin hafizalardaki tazeliğini sürekli muhafaza ettirebilmek için ulusal medya platformlarında kamu spotları şeklinde yayınlara daha sık yer verilmelidir. İlköğretim sınıflarından eğitime başlanarak müfredatlarda orman sevgisi, orman yetiştiriciliği, orman yangınları ve verdiği zararlar ile alınacak önlemlere daha çok yer verilmesi, genç kuşaklarda bilinç oluşturulması açısından faydalı olacaktır. Birçok ülkede bulunan, gençlerin ve çocukların orman ve ormancılık faaliyetleri ile ilgili bilgi ve bilinç düzeyini arttırmayı hedefleyen "orman (doğa) okulları"nın hayata geçirilmesi ile özellikle küçük yaşlardan itibaren doğru bilgi, bilinç ve algıların oluşturulması sağlanabilir. Bu kapsamdaki eğitimlerin mevcut müfredatla bütünleşik olarak planlanmasına özen gösterilmelidir. Son yıllarda TÜBİTAK tarafindan desteklenen "Doğa Eğitimi Projeleri" de yine aynı amaca hizmet eden ve çeşitli toplum kesimlerinden katılımcıları doğa ve orman ile buluşturan etkinlikler olup bu projelere yönelik desteklere devam edilmelidir.

Sosyal medyanın etkin kullanımı sayesinde tüm toplum kesimlerine hızlı bir şekilde ulaşmak mümkündür. $\mathrm{Bu}$ açıdan "geleceğe nefes" çalışmasının sosyal medya araçları kullanılarak toplum kesimlerine ulaşma başarısı değerlendirilmelidir. Ayrıca bölge ve işletme müdürlükleri düzeyinde de sosyal medya araçları, profesyonel birimler/görevliler tarafindan yönetilmelidir.

Özellikle anız yakma ve tarla-bahçe temizliği konusunda halkın bilinçlenmesi için gerekli uyarılar yapılmalı, anız yakmanın nedenleri analiz edilerek bu sorunun çözümü için etkin çalışmalar yapılmalıdır. Toplumda "yanan alanların başka amaçlarla (otel, tatil köyü vb.) kullanılacağı" konusunda algılar yaygın olarak bulunmaktadır. Ancak orman yangınları ile zarar gören alanlar en kısa sürede ağaçlandırılmakta ve Anayasamızın 169. maddesi gereğince yanan alanların başka bir amaca tahsis edilmesi söz konusu olmamaktadır. Bu bağlamda özellikle habere konu olmuş büyük yangınlardan sonra yapılan ağaçlandırma çalışmaları 
sonucunda yanan alanların son durumu paylaşılarak bu algıların değişmesi sağlanabilir.

- Rekreatif ihtiyaçlar: Nüfus artışı ve toplumun yaşam tarzındaki değişikliklerle birlikte doğa tabanlı rekreasyonel etkinliklere talep gün geçtikçe artmakta, ancak mevcut alanlar bu talepleri karşılayamamakta, bu nedenle talebin karşılanması için orman içi mesire alanları ve korunan alanlar içerisinde yeni günübirlik kullanım alanları oluşturulmaktadır. Ancak bu alanların bir kısmının ücretli olması, özellikle bu alanların kalabalık olduğu dönemlerde bazı insanların daha sessiz ve doğal olduğu düşüncesiyle kontrolsüz bir şekilde orman içinde piknik vb. rekreatif faaliyetlere yönelmesi yangın riskini arttırabilmektedir. $\mathrm{Bu}$ konuda toplumsal bilincin arttırılması, kamu kurumları (OGM, DKMP vb.) ve yerel yönetimler (Belediyeler vb.) tarafından yeni rekreasyonel alanların oluşturulması ve yangın riskinin yüksek olduğu dönemlerde yerleşim birimleri yakınlarındaki orman alanlarının düzenli denetimi gibi önlemler ile yangın riski azaltılabilecektir.

- Yangin sayı ve nedenlerinin analizi: Yangın sezonu başlamadan önce geçmiş yıllarda sayı ve alan olarak hangi orman işletme müdürlügünde, hangi orman işletme şefliğinde, hangi köyde ve mevkide daha çok yangın çıkmış irdelenmeli ve nedenleri araştırıldıktan sonra gerekli tedbirler alınmalıdır. Yangınların yoğunlaştığı yerlerde, ilk müdahale araçlarının buna göre konuşlandırılması veya devriyesi, yangın ekibi sayısının bu alanlarda kalıcı olarak artırılması gibi uygulamalara ağırlık verilmelidir. Yangın çıkış nedenlerinin doğru olarak tespiti yapılırsa yangın öncesi alınacak tedbirlerde karar alınması ve kararlardaki isabet oranı yüksek olacaktır.

- Mevzuat geliştirme: "Orman Yangınlarının Önlenmesi ve Söndürülmesinde Uygulama Esasları” isimli 1995 yılında yürürlüğe giren 285 sayılı Tebliğ günümüzün ihtiyaçlarına yeterli cevap veremediği için yenilenmesine ihtiyaç vardır. Ayrıca 2010 yılında yürürlüğe giren 6665 sayılı "Yanan Alanların Rehabilitasyonu ve Yangına Dirençli Ormanlar Tesisi Projesi” isimli Tamim Eylül 2014'te yenilenerek 6976 sayılı Tamim olarak yürürlüktedir. Ancak bu hususta bilgi ve tecrübenin artmasına paralel olarak Tamimim bazı yönleriyle değiştirilmesi gerektiği meslektaşlar tarafından dile getirilmektedir.

- Olay yeri incelemesi-kriminal çalışmalar: Olay yeri incelemesi; yangın nedeninin tespiti, değerlendirme yapılması ve yerel/bölgesel/ulusal politikalar/önlemler belirlenmesi açısından çok önemlidir. Bu kapsamda adli tıp, polis/jandarma kriminal gibi akredite olmuş, bilimsel tabana oturtulmuş veriler sunan, delil olarak kabul edilen tespitler yapabilecek birimlerin kurulması zorunludur. Bu birimlerin altında her bölgede yangın nedenlerinin tespiti için görev yapacak ekipler oluşturulmalı, orman yangınlarının söndürülmesinde görevli personel aynı zamanda kriminal farkındalık eğitimleri alarak bu konuda yetiștirilmelidir. Bununla birlikte olay yeri incelemelerinin tüm kolluk görevlileriyle eşgüdümlü olarak yürütülmesi faydalı sonuçlar sağlayacaktır.

- Personel eğitimi ve deneyim: Yangınla mücadele personelinin (işçi, mühendis ve özellikle operatörlerin) teknik yönden yapılacak eğitimlerinin yanı sıra motivasyon, kararlılık, irade ve inisiyatif kullanma yönünden iyi yetiştirilmesi ve bu eğitimlerin süreklilik arz etmesi gerekmektedir. Bunun yanında uzmanlaşmış teknik personelin rotasyonla başka görev ve yerlere atanması nedeniyle orman yangınları konusunda kurumsal hafizanın zayıflamış olması önemli bir sorun oluşturmaktadır. Bu kapsamda personel rotasyonu uygulamaları yeniden değerlendirilmelidir.

- Işçi sayısı: 2011 yılından itibaren 2020 yılı dâhil yangın müdahale işçisi sayısı sırasıyla 8386, 8860, 9619, 9642, $9367,9182,9255,8138,8566$ ve 8388 şeklindedir. Yani son on y1l boyunca daha fazla işçiye ihtiyaç olmasına rağmen yeterli düzeyde artış göstermediği, aksine son üç yılda önemli bir azalma yaşandığı görülmektedir. Bu eksikliğin ivedilikle giderilmesi gereklidir. Bu kapsamda doğrudan işçi istihdamının yanında yangınla mücadelede serbest ormancılık büro ve şirketlerinden hizmet alımının yaygınlaştırılması ve yapılan uygulamaların aksayan yönlerinin giderilmesi ile daha etkili hale getirilmesi üzerinde çalışılmalıdır.

- Orman bakımı çalıșmaları ve ENH'ler: Yangınların etkisinin azaltılması için orman yangınları ile mücadelede önleyici faaliyetlerden olan ve süreklilik arz etmesi gereken orman bakımlarının (silvikültürel müdahale) ihmal edilmeksizin yapılması gereklidir. Trafik yoğunluğu fazla olan yol kenarları öncelikli olmak üzere yol kenarlarında bulunan aşırı yanıcı yükü (orman altı şüceyrat) kaldırılmalıdır. Orman içinden geçen ENH'lerin gecikmiş bakımları en kısa sürede yapılmalı ve eskimiş olanlar yenilenmelidir. Buna ek olarak ENH altındaki yanıcı maddenin temizlenmesinin çoğunlukla ihmal edildiği ve rüzgârlı havalarda bu alanlarda büyük yangınlar görülmesi nedeniyle yangın sezonu öncesinde gerekli temizliğin yapılmasına önem verilmelidir.

- Teknoloji kullanımı: Ormanlar, yangın ve diğer suçlara karşı kamera, fotokapan ve dron gibi teknolojik cihazlarla takip edilmeye başlanmıştır. 2021 yılı yangın sezonunda Adana, Isparta, İzmir ve Muğla'da konuşlanan 4 adet İHA ile de yangına hassas orman alanlarının gözetlenmesi gerçekleştirilmektedir. Kritik alanların bu araçlarla özellikle sıkı bir şekilde gözlem altında tutulması gereklidir. Ayrıca orman yangınlarının nedenlerinin ve faillerinin bulunması ve bunların delillendirilerek yargıya taşınması oldukça güç olduğundan ormanlık alanları tarayarak kayıt yapan hava araçları sayesinde gerçek suçluların tespitine de katkı sağlanabilecektir.

Sonuç olarak; orman yangınlarının gelecekte bugünden daha fazla çıkma ve büyük yangınların sıklığının artma ihtimali bulunmaktadır. Çünkü yangının çıkması ve büyümesi üzerinde etkili olan nüfus yoğunluğunun artması ve iklim değişikliği ile beraberinde sıcak ve kurak yılların daha sık yaşanması bu tehlikeyi arttırmaktadır. Orman yangınlarının nedenlerinin kapsamlı irdelenmesi, sosyoekonomik etkilerinin en aza indirilmesi ve yöresel önlemlere ağırlık verilmesi, yangınların çıkma ve büyüme potansiyellerini azaltmak suretiyle ormanların yangın riskine karşı daha dayanıklı hale getirilmesi, böylelikle yangın söndürme potansiyelinin artırılması, yanıcı madde 
yükünün azaltılması, orman yangınları yönetim planlamasına geçilmesi ve bütün bu konuları kapsayan bilimsel çalışmaların artırılmasına ihtiyaç bulunmaktadır.

\section{Kaynaklar}

Avc1, M., Korkmaz, M., Alkan, H., 2009. Türkiye'de orman yangınlarının nedenleri üzerine bir değerlendirme. 1. Orman Yangınları İle Mücadele Sempozyumu, 07-10 Ocak, Antalya, s. 33-45.

Baltacı, U, Yıldırım, F., 2021. Muğla Orman Bölge Müdürlüğü’nde orman yangını riskinin cbs tabanlı çok kriterli analizi ve haritalandırılması. Ormancılık Araştırma Dergisi, 8 (1): 1-11.

Bilgili, E., Sağlam, B. 2003. Fire behavior in maquis fuels in Turkey. Forest Ecology and Management, 184: 201-207.

Bilgili, E., Dinç Durmaz, B., Sağlam, B., Baysal, İ., Küçük, Ö., 2010. Türkiye'de 2008 yılında çıkan büyük orman yangınlarının değerlendirilmesi. III. Ulusal Karadeniz Ormanc1llk Kongresi, Artvin, 20-22 Mayıs, s. 1270-1279.

Bilgili, E., 2020. Türkiye'de orman yangınlarına genel bir bakış. Yeşil Dünya, Orman Mühendisleri Odası, 57(1-2-3): s. 58-67.

Calda, B., An, N., Turp, M.T., Kurnaz, M.L., 2020. Effects of climate change on the wildfires in the Mediterranean Basin. International Journal of Advances in Engineering and Pure Sciences. 1: 15-32.

Coşgun, U., Yolcu, İ., Tolunay, A., Orhan, K.H., 2010. Antalya Orman Bölge Müdürlügünde Orman Yangınlarına Neden Olan Sosyo-Ekonomik Faktörlerin Belirlenmesi. Batı Akdeniz Ormancılık Araştırma Enstitüsü Müdürlüğü, Teknik Bülten Serisi, No: 40, Antalya.

Çoban, H.O., Özdamar, S., 2014. Mapping forest fire in relation to land-cover and topographic characteristics. Journal of Environmental Biology, 35(1): 217-224.

Çoban, H.O., Bereket, H., 2020. Visibility analysis of fire lookout towers protecting the Mediterranean forest ecosystems in Turkey. Sumarski List, 144(7-8): 393-407.

Çoban, H.O., Erdin, C., 2020. Forest fire risk assessment using GIS and AHP integration in Bucak Forest Enterprise, Turkey. Applied Ecology And Environmental Research, 18(1): 15671583.

Dinç Durmaz, B., 2014. Aralama görmüş genç kızılçam ağaçlandırma alanlarında yangın davranışı. Doktora Tezi, Karadeniz Teknik Üniversitesi, Fen Bilimleri Enstitüsü, Trabzon.

Duran, C., 2014. Mersin ilindeki orman yangınlarının başlangıç noktalarına göre mekânsal analizi (2001-2013). Ormancıllk Araştırma Dergisi, 1, A, 1:1, 38-49.

Göktepe, S., 2011. Muğla-Fethiye ormanlarında yangın sorunu, yangınların dağılımı ve yangınlar üzerinde etkili olan ekolojik faktörler. Yüksek Lisans Tezi, Süleyman Demirel Üniversitesi, Fen Bilimleri Enstitüsü, Isparta.

Güney, C.O., 2013. Antalya-Manavgat yöresi ormanlarında tutuşma riskinin coğrafi dağılım modellemesi. Yüksek Lisans Tezi, Süleyman Demirel Üniversitesi, Fen Bilimleri Enstitüsü, Isparta.

İSKİ, 2021. Kök Neden Analizi (Bulgularda Tespit Edilen Hususların Sebeplerinin Neler Olduğuna İlişsin Yapılacak Analiz Çalışmaları Hakkında Açılamalar). https://www.iski.gov.tr/web/assets/SayfalarDocs/icdenetimfiles /icdenetim/EK27.pdf (Erişim 17/08/2021)

Kavcin, A.B., Kesler, E., 2019. Orman Yangınlar1-Olay Yeri İnceleme ve Kriminal Yaklaşım. İkinci Adam Yayınları, İstanbul.

Kaya, Ş.D., 2017. Root cause analysis: examples of scenario. Gümüşhane University Journal of Health Sciences, 6(4): 247251.

Kurt, B., 2014. Türkiye'de orman yangınlarının coğrafi dağıllış1. Yüksek Lisans Tezi, Ankara Üniversitesi, Sosyal Bilimler Enstitüsü, Ankara.
Küçük, Ö. 2004. Yanıcı madde tipleri ve yangın davranıșına bağ yangın potansiyelinin belirlenmesi ve haritalanması. Doktora Tezi. Karadeniz Teknik Üniversitesi. Fen Bilimleri Enstitüsü. Trabzon.

Küçükosmanoğlu, A. 1998. Forest fires in Turkey. İstanbul Üniversitesi, Orman Fakültesi Dergisi, 48(1): 53-59.

MGM, 2021. Türkiye 2020 Yılı İklim Değerlendirmesi. 18 s., Ankara

Neyişçi, T., 1988. Orman yangınlarına ekolojik yaklaşım. Orman Mühendisliği, 25(2): 26-29.

Neyișçi, T., 1994. Anız, orman, yangın, araç, trafik, kaza. Orman Mühendisliği, 31(8): 7-8.

Neyişçi, T., Ayaşlıgil, Y., Sönmezıșık, S., 1999. Yangına dirençli orman kurma ilkeleri. Tübitak-Togtag-1342, TMMOB Orman Müh. Odası Yayın No: 21, Ankara.

Neyişçi, T., Şirin, G., Sarıbaşak, H., 2002. Batı Akdeniz Bölgesi'nde Orman Yangını Tehlikesinin Düşürülmesinde Denetimli Yakma Tekniğinin Uygulama Olanakları. TÜBITTAK Projesi, Proje No: TARP-2170, Türkiye Ormancilar Derneği Yayını. Yayın No: 2, Ankara: $63 \mathrm{~s}$.

Nulty, D.D., 2008. The Adequacy of response rates to online and paper surveys: what can be done? Assessment \& Evaluation in Higher Education, 33(3): 301-314.

OGM, 2009. Sürdürülebilir Orman Yönetimi Kriter ve Göstergeleri 2008 Y1lı Raporu. Orman Genel Müdürlüğü, Ankara, 142s.

OGM, 2014. OGM Alg1 Araştırması. Orman Genel Müdürlüğü, Analitik Teknik Araştırma ve Danışmanlık Ltd. Şti., Ankara, $207 \mathrm{~s}$.

OGM, 2018. Orman Genel Müdürlüğü Stratejik Plan (2019-2023). Orman Genel Müdürlüğü, Ankara, 63s.

OGM, 2019. Orman Yangınlarıly Mücadelede Yenilikçi Yaklaşımlar Çalışma Grubu Belgesi, III. Tarım ve Orman Şûras1, 2019, Ankara.

OGM, 2020. Sürdürülebilir Orman Yönetimi Kriter ve Göstergeleri 2019 Türkiye Raporu. Orman Genel Müdürlügüü, Ankara, $215 \mathrm{~s}$.

OGM, 2021. Orman Yangınlarıyla Mücadele Değerlendirme Raporlar1. Ankara

OMO, 1994. Gelibolu Yarımadası Tarihi Milli Parkı Yangını. Orman Mühendisleri Odası Yayın No: 18, Ankara, 49s.

Öner, B., Çalışkan Eleren, S., Salihoğlu, N.K., 2019. Turistik sahil bölgelerinde atık yönetimine bir örnek: Bodrum. Uludağ Üniversitesi, Mühendislik Fakültesi Dergisi, 24(1), 207-218.

Özden, S., Kılıç, H., Ünal, H. E., Birben, Ü., 2012. Orman Yangını İnsan İlişkisi, Türkiye Ormancılar Derneği Yayını, Ankara.

Sağkaya, A., 2009. Yangın öncesi ekiplerin organizasyonu, eğitimi ve motivasyonu. I. Orman Yangınları İle Mücadele Sempozyumu, 07-10 Ocak, Antalya, s. 9-11.

Sağlam, B., 2002. Meteorolojik faktörlere bağlı yanıcı madde nem içerikleri ve maki tipi yanıcı maddelerde yangın davranıșı. Doktora Tezi. Karadeniz Teknik Üniversitesi. Fen Bilimleri Enstitüsü. Trabzon.

Sağlam, B., Bilgili, E., Küçük, O., Durmaz, B. D., 2008. Fire behavior in Mediterranean shrub species (Maquis). African Journal of Biotechnology, 7(22): 4122-4129.

Tavşanoğlu, C. 2009. Akdeniz havzası ormanlarında yangın sonrası kendiliğinden gençleşme. Orman Yangınları ile Mücadele Sempozyumu. 7-10 Ocak. Antalya, s. 310-317.

Türkeş, M., 2020. Kuraklık Şiddetli, Su Sıkıntısı Ciddi. Aynalı Pazar, 8-9. Canakkale

Türkeş, M., Altan, G., 2012. Muğla Orman Bölge Müdürlüğü'ne bağlı orman arazilerinde 2008 yılında çıkan yangınların kuraklık indisleri ile çözümlenmesi. Uluslararası İnsan Bilimleri Dergisi, 9: 912-931.

Zile, M., 2018. Orman yangınlarının olay yerinde analizi, kusurluların ile kusur oranlarının belirlenmesi ve alınması gereken önlemler. Anadolu Orman Araştırmaları Dergisi, 4(2): 89-97. 